\title{
Goals, Strategies, and Achievements in the Internationalization of Higher Education in Japan and Taiwan
}

\author{
Hsuan-Fu Ho ${ }^{1}$, Ming-Huang Lin $^{2} \&$ Cheng-Cheng Yang ${ }^{3}$ \\ ${ }^{1}$ Graduate Institute of Educational Administration and Policy Development, National Chiayi University, Taiwan \\ ${ }^{2}$ Teacher Education Center, National Chiayi University, Taiwan \\ ${ }^{3}$ National Chiayi University, Taiwan \\ Correspondence: Ming-Huang Lin, Teacher Education Center, National Chiayi University, Taiwan. Tel: \\ 886-5226-3411. E-mail: lin5053@mail.ncyu.edu.tw
}

Received: October 28, 2014 Accepted: December 9, 2014 Online Published: February 25, 2015

doi:10.5539/ies.v8n3p55 URL: http://dx.doi.org/10.5539/ies.v8n3p55

\begin{abstract}
International knowledge and skills are essential for success in today's highly competitive global marketplace. As one of the key providers of such knowledge and skills, universities have become a key focus of the internationalization strategies of governments throughout the world. While the internationalization of higher education clearly has certain benefits for students, schools, the national economy, and the international community, each country gives a different degree of importance to each of these various benefits. The purpose of this study was threefold: 1) to determine which benefits of the internationalization of education are deemed most important in Taiwan and Japan; 2) to determine which measures are most effective for realizing these benefits; and 3) to determine the extent to which these measures have actually been carried out. A questionnaire was used to obtain the views of 100 professors, 50 in Taiwan and 50 in Japan, as to the current situation in their respective countries. The results indicate that there are significant differences between the two country's reasons for promoting the internationalization of education, as well as in their respective internationalization strategies.
\end{abstract}

Keywords: higher education, internationalization, comparative education, strategic management

\section{Introduction}

Globalization and the growing importance of the knowledge economy have become perennial challenges facing all countries in the past two decades. Surviving the fierce global competition in the new millennium requires a high level of international knowledge and skills. Since universities by nature are centres of knowledge generation and bases for the cultivation of human resources, they have thus been targeted by most governments as the crux for promoting internationalization.

The internationalization of higher education can be defined as 'the process of integrating an international dimension into the teaching, research, and service functions of an institution of higher education'. This can be achieved by a variety of strategies, including: encouraging students to study abroad; recruiting foreign students; strengthening cooperation with overseas universities; establishing international education centres; integrating international knowledge into the curriculum; and promoting the publication of articles in international journals.

In determining the optimal strategy for the internationalization of education for a given country, it is necessary to first determine the nation's reasons for promoting internationalization. Ma (2002) suggests that internationalization of education is both an 'inevitable fact' and a 'necessary value', and that the goals should be established at the very beginning of the internationalization process so as to facilitate the assessment of the value and the selection of strategic alternatives. Marginson (2010) argues that inasmuch as higher education is simultaneously global, national, and local, it is necessary to have a full understanding of the goals and dynamics of internationalization at various different levels - individual, institutional, national, and global — and how to go about making the most effective improvements in the process and the results.

Universities in Taiwan and Japan are no exception. Japan was the first country in the region to actively promote internationalization. In 1983 the Japanese government announced the ' 100,000 by 2000 ' project to recruit at least 100,000 international university students by the year 2000. In 2001 the government of Japan further adopted its 'Global 30' plan for transforming 30 universities into world-class institutions of higher learning. Finally, in 2008 
the government announced a plan to attract 300,000 international students to enrol at Japanese universities by 2020.

By contrast, the focus of the internationalization strategy in Taiwan has been on enhancing the overall quality of university education. The first major step came in 2004 when the government announced a plan for upgrading its leading institutions of higher education to the level of world-class universities. A further step was taken in 2011 when the Ministry of Education (MOE) published the 'White Paper on International Education for Primary and Secondary Schools' which laid out plans for improving students' international competence.

There are a number of significant differences in the goals and strategies of the internationalization of education in Japan and Taiwan. The main strategy employed in Taiwan is to improve the quality of higher education, in hopes of enhancing the international rankings of its universities. As for the internationalization of the curriculum, the focus has been on the primary and secondary school levels. While Japan's strategy also includes improving the overall quality of its universities so as to enhance their position in the intensely competitive overseas education market, the focus has been on recruiting larger numbers of foreign students. This constitutes a significant difference in the strategies of the two nations. The purpose of this research was to determine whether the adoption of these different strategies is the result of differences in the respective goals of internationalization in Taiwan and Japan, and to evaluate how effective these strategies have been in reaching these goals.

Faculty members play a pivotal role in the process of the internationalization of education. Because they often serve as the facilitators of internationalization, a deeper understanding of faculty members' views on the goals, strategies, and achievements of internationalization is crucial for successful internationalization (Dewey \& Duff, 2009). Therefore, faculty members were targeted as the research participants in this study. The research questions of this study are as follows:

1) What are the major goals of internationalization?

2) What is the relative weight of each goal? Are there any differences between Taiwan and Japan in this respect?

3) Which strategies are most effective for realizing which goal?

4) What strategies have been most successful in Taiwan and Japan?

\section{Literature Review}

\subsection{The Internationalization of Higher Education in Japan}

Starting at the beginning of the $21^{\text {st }}$ century, a number of significant reforms of the higher educational system have been proposed in Japan, one of the key factors of these proposals being the internationalization of education. First of all, faced with a tremendous decrease in the college-age population, universities have had to seriously consider how to expand their pool of applicants. In addition, the government is striving to bring the quality of its universities up to par with the leading universities in the West. Also, Japanese companies struggling to survive in an increasingly globalized market now expect new employees to be equipped with international perspectives and skills (Doyon, 2001; Horie, 2002).

The Japanese government instituted the ' 100,000 by 2000 ' plan in 1983 , aiming to promote the internationalization of education at both the institutional and national levels by recruiting 100,000 international university students by 2000 . The plan focussed on raising the quality of education and research to meet global standards, offering scholarships and tuition waivers to international students, increasing opportunities for Japanese language training, and encouraging Japanese students to study abroad (Horie, 2002).

The plan was successful in terms of increasing the numbers of international students (from 10,428 in 1983 to 64,011 in 2000). However, many have pointed out that quality of education is as important as an increase in the number of international students, and in 2001 the government established its 'Global 30' plan aimed at transforming 30 universities into world-class institutions of higher learning. Further, in 2008 the government set a goal of attracting 300,000 international university students by the year 2020 (Yonezawa, 2011). Hence, Japan's efforts have focussed on increasing the number of overseas students, while simultaneously enhancing the quality of the educational services provided.

\subsection{The Internationalization of Higher Education in Taiwan}

Rather than striving to expand the number of international students, the focus of Taiwan's efforts has mainly been on fostering world-class universities. Although Taiwan is also making efforts to recruit more foreign students, these efforts are mainly adopted by less prestigious universities as a survival strategy in a rapidly shrinking home market (Chen \& Lo, 2013). 
Faced with fierce economic competition due to globalization, the government of Taiwan realized that its education system was poorly equipped to produce the type of human resources required in a globalized market, and began to integrate an international dimension into the educational system, primarily at the lower levels (Law, 2004). Thereafter, Taiwan's entry into World Trade Organization (WTO) in 2001 and its subsequent signing of the General Agreement on Trade in Services (GATS) have accelerated the internationalization of education (Chen \& Lo, 2007; Lo, 2009).

In 1998 Taiwan launched a five-year program for promoting the academic excellence of universities, and in 2002 launched another five-year plan to enhance the quality of higher education. Further, in 2003 the government announced the 'Challenge 2008' national development plan for promoting the internationalization of higher education. Thereafter, in 2005 the government began to focus on enhancing the quality of its institutions of higher education and established a program for developing first-class universities and top research centres commonly called the 'Five-year, 50-billion program', which allocated NT $\$ 50$ billion (approximately US $\$ 1.65$ billion) for bringing at least one university into the rank of the world's top 100 universities (Lo, 2009). This aim was achieved in 2009when National Taiwan University was ranked 95 in the Times Higher Education-QS World University Rankings.

Finally, in 2011 the MOE published its 'White Paper on International Education for Primary and Secondary Schools', which laid out strategies for enhancing students' knowledge of English and increasing their understanding of different cultures as a way of equipping them with the skills required in an internationally competitive job market.

\subsection{Goals of the Internationalization of Higher Education}

Selecting the most effective strategy for promoting educational internationalization begins with determining the goals for doing so. For this reason this research aimed to elucidate the attitudes faculty members have concerning the goals of the internationalization of higher education. In general, it is expected that such internationalization will bring various practical benefits, and the related literature uses such interchangeable terms as 'expectations', 'motives', and 'pursuing benefits' (Yang, Webster, \& Prosser, 2011). This section examines the goals (expected benefits) of internationalization, and the results were used to develop the questionnaire items.

Marginson (2010) claims that higher education and knowledge are simultaneously global, national, and local, such that in addition to providing opportunities for individuals and enhancing the quality of schools, the internationalization of higher education also fosters domestic economic development and promotes international understanding and cooperation. Thus the internationalization of higher education can be described as having two main goals. The first goal is On-campus Benefits, those which directly relate to the university and its students. The two sub-goals included in On-campus Benefits are Student Benefits and Institutional Benefits. The second goal is Off-campus Benefits, the sub-goals of which are Domestic Benefits and Global Benefits.

Pyvis and Chapman (2007) investigated the reasons why university students choose to study abroad, and found that students often believe that doing so will provide a competitive edge in the job market. He and Chen (2010) found that study abroad helps to broaden one's worldview, inspires personal growth, enhances one's self-image, and creates a more positive attitude towards other cultures. They also found that student exchange programs foster international understanding and a multicultural perspective. C. Boronico and J. Boronico (2010) suggest that study abroad enhances a student's job prospects following graduation, since many employers value overseas study experience when hiring recent university graduates. Salisbury, Umbach, Paulsen, and Pascarella (2009) found that students who study abroad have a deeper understanding of global issues, a better appreciation of other cultures, stronger intercultural communication skills, and a more positive self-image. Sherry, Thomas, and Chui (2010) claimed that international study offers students the chance to explore a different culture, learn new ways of thinking, increase their self-esteem and confidence, and improve their cross-cultural knowledge and skills. Thus in this study the three Student Benefits were designated as Knowledge Enrichment, Language Competence, and International Career Competitiveness.

As for the Institutional Benefits of the internationalization of higher education, C. Boronico and J. Boronico (2010) claim that study abroad is fast becoming a critical component in higher education because it promotes intellectual, cultural, and personal growth. Mazzarol and Soutar (2008) argue that the global market for international students has become highly competitive and many institutions of higher education rely heavily on the fees paid by international students. Chen and Lo (2013) suggest that many nations and institutions of higher education regard internationalization largely as a way of generating additional revenues. Mortimer (1997) asserts that due to a lack of government funding, universities in the UK have to explore alternative sources of revenue, 
one of which is the recruitment of overseas students.

A number of studies have pointed out that internationalization helps create a multicultural learning environment for university students. For example, Ippolito (2007) argues that a multicultural learning environment should be promoted to help students adapt to the increasing internationalization of higher education. Guo and Chase (2011) found that in the Canadian academic environment programs tend to ignore the needs of international graduate students and suggest that an internationalized curriculum and learning environment are the keys to promoting the academic success of international students. Another important benefit of internationalization is its positive influence on a university's reputation. For example, the ranking system used by the Times Higher Education World University Rankings takes into account such criteria as citations in international publications and the ratio of overseas students to teaching faculty (Taylor \& Braddock, 2007). Frolich (2006) found that at Norwegian institutions of higher education the primary goal of internationalization is not economic benefit, but rather enhancing academic quality.

A number of studies have pointed out the various Off-campus Benefits of the internationalization of higher education. For example, Horie (2002) suggests that governments promote internationalization because they believe that it will promote international understanding, enhance the nation's understanding of global issues, and contribute to its economic and social systems. He also suggests that internationalization is seen as a way of enriching a university's learning environment and helping institutions to attract more students, both domestic and international. Pyvis and Chapman (2007) argue that internationalization of education is beneficial to national interests, and point out that overseas students constituted Australia's sixth largest export earner. Knight (2004) points out that the benefits of internationalization include the strengthening of human resources, enhancing strategic alliances with neighbouring countries, increasing commercial trade, building a national cultural identity, and promoting intercultural understanding between nation states. Gacel-Avila (2005) asserts that the key importance of the internationalization of higher education is its role in promoting a sense of global citizenship.

\section{Methodology}

The main goals of this research were to identify the major benefits of the internationalization of university education in Taiwan and Japan; to calculate the relative weight of each benefit; and to compare the importance given to these benefits by faculty members. The Analytic Hierarchy Process (AHP) was adopted as the major instrument for measuring the relative importance of the benefits, and ANOVA and a t-test were used to determine if there were significant differences between the views of the faculty members in the two nations. Finally, correspondence analysis (CA) was used to create a perceptual map clarifying which internationalization measure is best suited to realizing a given benefit.

\subsection{The Analytic Hierarchy Process}

AHP was adopted as the major instrument because it is highly effective in determining the relative importance of various factors. The AHP procedure begins by determining the relevant factors, and then structuring them into a hierarchy chart, with the primary goal at the first level. The second level consists of the secondary goals that together constitute the primary goal. In turn, each goal is has two sub-goals on the next lower level. Thereafter, the relative importance of each benefit was determined by comparing them in pairs, and a positive reciprocal matrix was used to calculate the relative weights of each benefit. Finally, in order to ensure the reliability and validity, an eigenvector $\lambda_{\max }$ was used to assess the consistency of the structure.

The AHP structure used in this research is shown in Figure 1. The primary goal, located at the highestlevel (far left), is the Internationalization of Higher Education. On the second level are the two goals of internationalization: On-campus Benefits and Off-campus Benefits. On the third level are the four sub-goals: Student Benefit, Institutional Benefit, Domestic Benefit, and Global Benefit. On the fourth level are the twelve benefits of the Internationalization of Higher Education. 


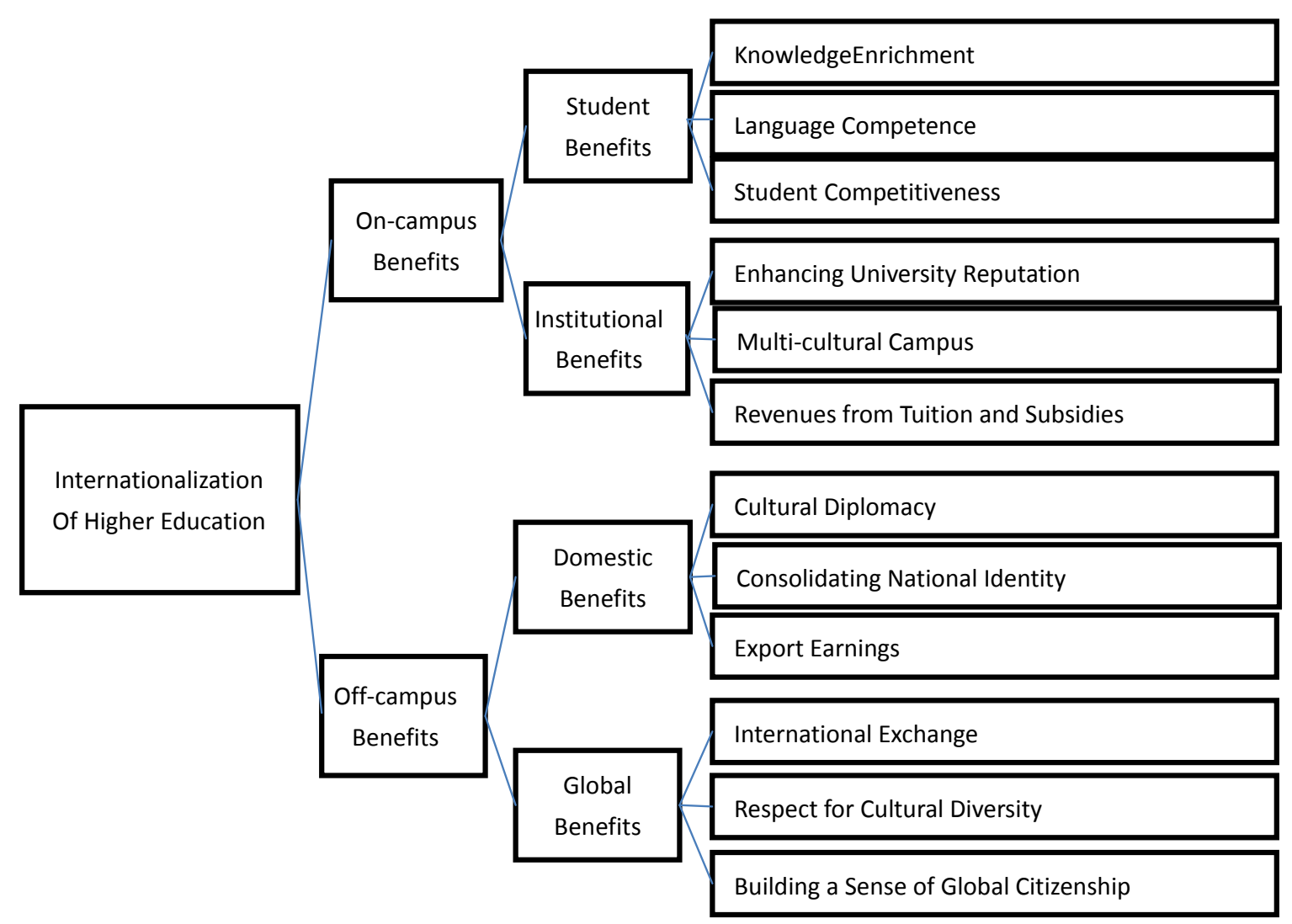

Figure 1. The AHP structure used in this research

\subsection{Design of the Questionnaire}

Two questionnaires were developed for this research. The first questionnaire was written in Chinese and was used to survey the opinions of professors in Taiwan; the second questionnaire was a translation of the first questionnaire into Japanese, and was used to survey the opinions of the Japanese professors. The questionnaire consisted of four parts. The first part collected the participants' background information; the second part consisted of fifteen pair wise questions for AHP analyses. The third part of the questionnaire consisted of ten questions on the internationalization strategies being used in Taiwan and Japan. The last part consisted of ten questions to determine the effectiveness of these strategies.

\subsection{Participants}

The first questionnaire was sent to 50 professors from five different universities in Taiwan; a total of 42 questionnaires were filled out and returned, resulting in an $84 \%$ retrieval rate. Of those who returned the questionnaire, 29 were male, and 13 were female; 33 taught at schools located in urban areas, and nine taught at schools in rural areas.

The second questionnaire was sent to 50 professors in Japan; 47 were filled out and returned, resulting in a $94 \%$ retrieval rate. Of those who returned the questionnaire, 32 were male, and 15 were female; 38 of the participants taught at schools located in urban areas, and nine taught at schools in rural areas. From this data it can be seen that the participants in Taiwan and Japan had similar backgrounds.

\section{Research Results}

Microsoft Excel was adopted for the AHP procedure and used to calculate the comparative weights of the goals, sub-goals, and benefits.

Table 1 shows that the Taiwanese and Japanese participants were similar in the degree of importance they gave to the two goals. Yet, in comparison with their Japanese counterparts, the professors in Taiwan gave relatively more importance to On-campus Benefits, and gave rather less importance to Off-campus Benefits. 
Table 1. Weights of the two goals

\begin{tabular}{lcc}
\hline \multirow{2}{*}{ Goals } & \multicolumn{2}{c}{ Weight } \\
\cline { 2 - 3 } & Taiwan & Japan \\
\hline On Campus Benefits & 0.768 & 0.634 \\
Off Campus Benefits & 0.232 & 0.366 \\
\hline
\end{tabular}

Table 2 shows that the Taiwanese professors gave more importance to Student Benefits than their Japanese counterparts, while the Japanese professors gave more importance to Institutional benefits, Domestic Benefits, and Global Benefits.

Table 2. Weights of the four sub-goals

\begin{tabular}{llcc}
\hline \multirow{2}{*}{ Goal } & \multirow{2}{*}{ Sub-goal } & \multicolumn{2}{c}{ Weight } \\
\cline { 3 - 4 } & & Taiwan & Japan \\
\hline \multirow{2}{*}{ On-campus } & Student Benefits & 0.515 & 0.329 \\
& Institutional Benefits & 0.253 & 0.305 \\
\multirow{2}{*}{ Off-campus } & Domestic Benefits & 0.154 & 0.177 \\
& Global Benefits & 0.077 & 0.189 \\
\hline
\end{tabular}

Table 3 shows that both the Taiwanese and Japanese professors gave much importance to Knowledge Enrichment, Multicultural Campus, and Language Competence; and that both groups of participants gave less importance to Consolidating National Identity and Building a Sense of Global Citizenship. However, the Taiwanese professors gave much more importance to Student Competitiveness than did the Japanese professors, while the Japanese professors gave much more importance to Earnings from Tuition and Subsidies than did their Taiwanese counterparts.

Table 3. Weights of the 12 benefits

\begin{tabular}{|c|c|c|c|c|}
\hline \multirow{2}{*}{ Goal } & \multirow{2}{*}{ Sub-goal } & \multirow{2}{*}{ Benefit } & \multicolumn{2}{|c|}{ Weight } \\
\hline & & & Taiwan & Japan \\
\hline \multirow{6}{*}{ On- campus } & \multirow{3}{*}{$\begin{array}{l}\text { Student } \\
\text { Benefits }\end{array}$} & Knowledge Enrichment & 0.180 & 0.152 \\
\hline & & Language Competence & 0.140 & 0.100 \\
\hline & & Student Competitiveness & 0.195 & 0.078 \\
\hline & \multirow{3}{*}{$\begin{array}{l}\text { Institutional } \\
\text { Benefits }\end{array}$} & Enhancing University Reputation & 0.052 & 0.049 \\
\hline & & Multicultural Campus & 0.153 & 0.134 \\
\hline & & Earnings from Tuition and Subsidies & 0.048 & 0.121 \\
\hline \multirow{6}{*}{ Off-campus } & \multirow{3}{*}{$\begin{array}{l}\text { Domestic } \\
\text { Benefits }\end{array}$} & Cultural Diplomacy & 0.088 & 0.072 \\
\hline & & Consolidating National Identity & 0.031 & 0.031 \\
\hline & & Export Earnings & 0.035 & 0.073 \\
\hline & \multirow{3}{*}{$\begin{array}{l}\text { Global } \\
\text { Benefits }\end{array}$} & International Exchange & 0.033 & 0.064 \\
\hline & & Respect for Cultural Diversity & 0.027 & 0.081 \\
\hline & & Building a Sense of Global Citizenship & 0.018 & 0.044 \\
\hline
\end{tabular}

Next, we used the responses in the third part of the questionnaire to compare the extent to which ten different internationalization strategies have been implemented in Taiwan and Japan. Table 4 indicates that that both Japan and Taiwan have already made significant achievements in Recruiting International Students, Building Relationships with Schools Abroad, and Promoting Overseas Study and Exchanges; and that they have had less 
success in Recruiting Foreign Faculty, Encouraging Teachers to Participate in International Education, and Establishing Schools or Programs Abroad. As for differences between the two nations, Japan has done a better job than Taiwan in Recruiting International Students, Encouraging Teachers to Participate in International Education, and Promoting Overseas Study and Exchanges, while for all the other strategies, Taiwan has achieved more than Japan.

Table 4. Implementation of internationalization strategies in Taiwan and Japan

\begin{tabular}{lcc}
\hline Internationalization Strategies & \multicolumn{2}{c}{ Mean } \\
\cline { 2 - 3 } & Taiwan & Japan \\
\hline Recruiting International Students & 3.38 & 3.47 \\
Recruiting Foreign Faculty & 2.40 & 2.28 \\
Creating an English Campus & 3.00 & 2.11 \\
Integrating International Knowledge into Curriculum & 3.19 & 2.83 \\
Encouraging Teachers to Participate in International Education & 2.86 & 2.91 \\
Building Relationships with Schools Abroad & 3.48 & 3.34 \\
Promoting Overseas Study and Exchanges & 3.12 & 3.30 \\
Establishing Schools or Programs Abroad & 2.32 & 1.57 \\
Hosting International Conferences and Competitions & 3.21 & 2.23 \\
Promoting the Publication of Articles in International Journals & 3.50 & 2.36 \\
\hline
\end{tabular}

The last step was to use CA to produce a perceptual map displaying the relative position of each of the ten strategies in relation to the 12 benefits of internationalization. The data obtained from the third part of the questionnaire was used to calculate the effectiveness of each measure in relation to each benefit, and then CA was used to create the perceptual map (Figure 2). The Chi-square of 400.36 and the CR value of .000 indicated that the perceptual map created by CA was feasible. In the perceptual map it can be seen that Recruiting International Students is good for increasing Export Earnings; and Promoting the Publication of Articles in International Journals is good for Enhancing University Reputation. From the map it can also be seen that Recruiting Foreign Faculty helps with building a Multicultural Campus, Building a Sense of Global Citizenship, and Enhancing Student Competitiveness; Creating an English Campus is useful for Enhancing Students' Language Competence; and Integrating International Knowledge into Curriculum is good for students' Knowledge Enrichment. Finally, Building Relationships with Schools Abroad, Encouraging Teachers to Participate in International Education, and Hosting International Conferences and Competitions are all good strategies for promoting International Exchange and Consolidating National Identity. 


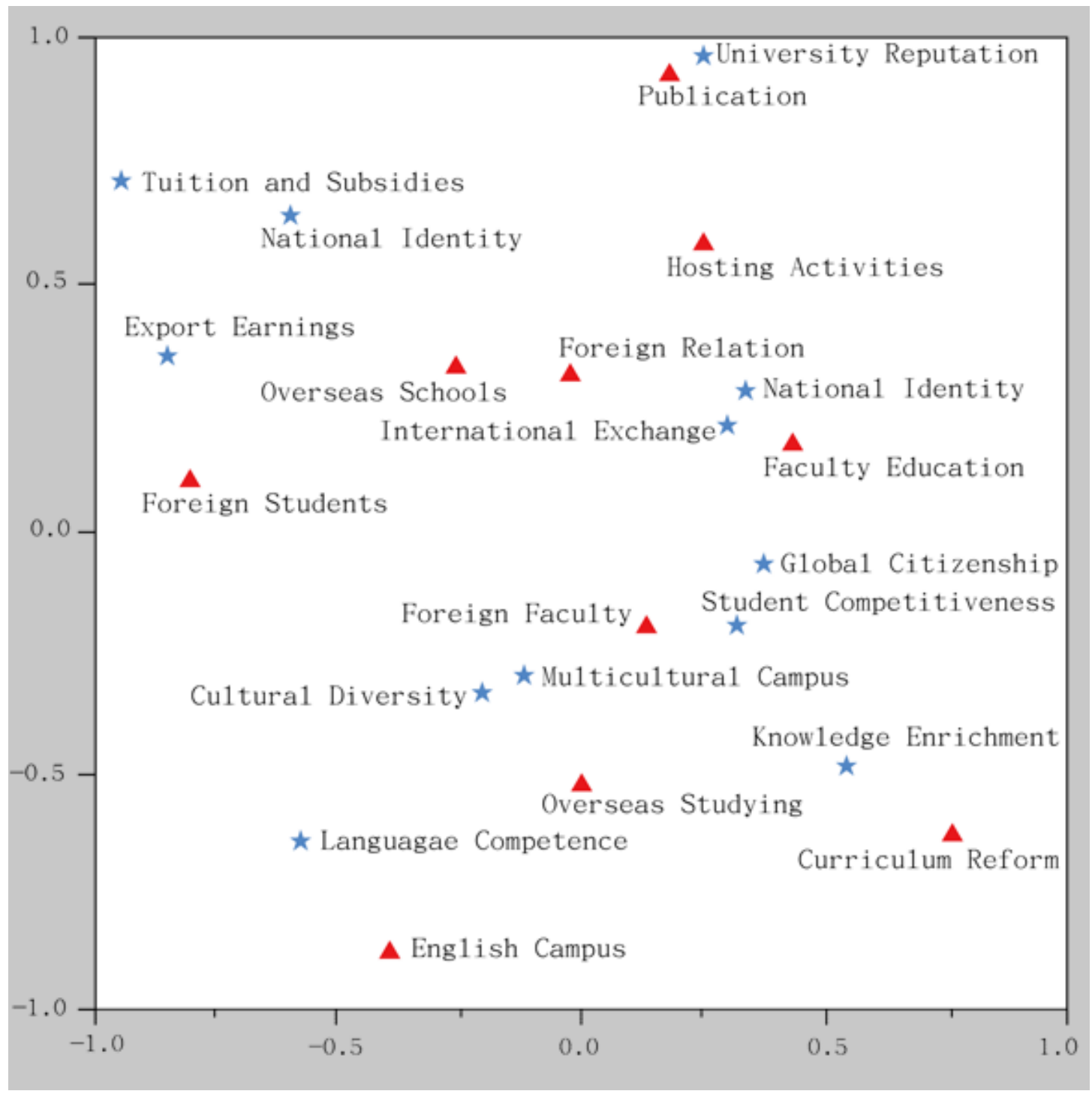

Figure 2. Perceptual map of the relationship between the ten strategies and 12 benefits

\section{Main Findings}

In response to the cultural and economic challenges posed by the relentless pace of globalization, in recent years governments around the world have begun to actively promote internationalization, a key element of which is the internationalization of higher education. In this research a questionnaire was used to elicit the views of professors in Taiwan and Japan as to the benefits of internationalization they deem to be most important, the extent to which various internationalization strategies have been implemented in their respective countries, as well as the results of these strategies. The findings of this research can serve as reference material for policy makers in Taiwan and Japan.

AHP was used to determine the relative importance the participants give to the various benefits of internationalization. The results indicate that professors in both countries believe that the most important benefits of internationalization are increasing students' international knowledge, enhancing their foreign language abilities, and creating a multicultural campus. Although a number of scholars have argued that an increased sense of national identity is one of the benefits of the internationalization of education, the participants in this study didn't see this as an important benefit.

In comparison with the Taiwanese participants, the Japanese professors gave more importance to the economic benefits internationalization has for a university. This is mainly because many of the Japanese participants teach at private universities, which don't receive any government funding, whereas private universities in Taiwan do 
receive some government funding.

It's also noteworthy that in comparison to their Japanese counterparts, the Taiwanese participants gave more importance to enhancing students' competitiveness in the international job market. This is mainly because Taiwan's economy is not as developed or internationally competitive as that of Japan, and Taiwanese companies tend to pay lower salaries than do foreign companies based in Taiwan. As a result, recent graduates in Taiwan are keen to find employment with a foreign company; thus the greater emphasis in Taiwan on enhancing students' international competitiveness. By contrast, recent graduates in Japan tend to seek work with Japanese companies, and if later on they do end up working abroad, it's usually for an overseas branch of the same company. This is why the Japanese participants gave less importance to international competiveness.

As for the extent to which various internationalization strategies have been implemented, the results indicate that there are some major differences between Taiwan and Japan. First of all, Japan is far ahead of Taiwan in terms of recruiting foreign students. There are four main reasons for this: 1) Recruiting foreign students is a top priority in the Japanese government's internationalization strategy, and before a university can open a new program it must first have a certain proportion of overseas students; 2) The birth rate began to decrease in Japan over a decade earlier than in Taiwan, so Japan has that much more experience in dealing with the effects of a shrinking university-age population; 3) Because private universities in Japan don't receive government funding, they are much more reliant on the tuition paid by foreign students; and 4) Overall, Japan's universities have a stronger academic reputation than those of Taiwan, so many students in the region are eager to study in Japan.

The results also reveal a major difference with respect to the importance given to publishing papers in international journals. Although Japan's universities are academically superior, the Taiwanese participants gave much more importance to publishing papers in international journals. This is mainly because Taiwan's internationalization strategy gives top priority to increasing the quality of higher education, and this entails annual school and faculty evaluations, a key criterion of which is the number of papers published in international journals. The results of these evaluations have a major bearing on faculty promotions and which schools remain open and which get closed. As a result, Taiwanese universities invariably strongly encourage their faculty members to publish their research in foreign journals. Another reason for this difference is that, due to the high quality of academia in Japan, most Japanese scholars publish their papers in Japanese journals and see less value in publishing their work in foreign journals. By contrast, because Taiwan's academic reputation is relatively weak, most Taiwanese scholars are eager to have their work published in a foreign journal, which they regard as an indication of the value of their research.

Finally, from the $\mathrm{CA}$ it can be seen that certain internationalization strategies are much more effective than others in bringing about a certain benefit. This needs to be kept in mind when formulating an internationalization strategy. The results indicate that in both Taiwan and Japan much importance is given to enriching students' international knowledge, creating a multicultural campus, and improving students' foreign language skills. The CA indicates that the most effective measure for enriching students' international knowledge is integrating international components into the curriculum; and that the most effective internationalization measure for improving students' foreign language ability is to create an English-friendly campus. Appointing prominent foreign professors is not only the most effective way to create a multicultural campus, but also enhances students' competitiveness in the international job market and increases their sense of global citizenship. However, the results also indicate that in both Taiwan and Japan there is room for improvement in all three of these internationalization strategies. Thus it is suggested that these three strategies be given more priority in the internationalization strategies of both Taiwan and Japan.

\section{Conclusions and Implications}

In this study it was found that there are significant differences between Taiwan and Japan in terms of the importance they give to the various benefits of the internationalization of education. Despite the researchers' best efforts to explain the reasons for these differences, it should be noted that this is primarily a quantitative study and that there may be other reasons for these differences. Thus it is suggested that a qualitative study be carried out in the future to provide further insight into this topic.

Second, as pointed out above, although a number of scholars have argued that an increased sense of national identity is one of the benefits of the internationalization of education, the participants in this study didn't see this as an important benefit. Thus the relationship between the internationalization of education and sense of national identity is a topic which needs to be further investigated.

This research highlights important managerial implications for higher education administration. For higher education institutions in Taiwan, since faculty value the importance of achieving student and institutional 
benefits, i.e. enriching student knowledge and competiveness and enhancing institutional reputation and multicultural campus. University managers in Taiwan could think of implementing strategies of recruiting foreign faculty because it relates to student competiveness and a multicultural campus. For higher education institutions in Japan, faculty place higher value on students' knowledge enrichment and multicultural campus and to generate earnings from tuition. University managers in Japan could consider strategies of establishing schools or programs abroad and admitting more international students to achieve the goals of multicultural campus and increasing institutional revenue.

\section{References}

Boronico, C., \& Boronico, J. (2010). Study abroad perspectives on institutional operations. Contemporary Issues in Education Research, 3(4), 13-20.

Chen, D., \& Lo, W. (2007). Critical reflections of the approaches to quality in Taiwan's higher education. Journal of Comparative Asian Development, 6(1), 165-186.

Chen, D., \& Lo, W. (2013). Internationalization or commodification? A case study of internationalization practices in Taiwan's higher education. Asia Pacific Education Review, 14(1), 33-41. http://dx.doi.org/10.1007/s12564-013-9246-0

Dewey, P., \& Duff, S. (2009). Reason before passion: Faculty views on internationalization in higher education. Higher Education, 58, 491-504. http://dx.doi.org/10.1007/s10734-009-9207-z

Doyon, P. (2001). A review of higher education reform in modern Japan. Higher Education, 41, 443-470. http://dx.doi.org/10.1023/A:1017502308832

Frolich, N. (2006). Still academic and national: Internationalisation in Norwegian research and higher education. Higher Education, 52, 405-420. http://dx.doi.org/10.1007/s10734-005-3080-1

Gacel-Avila, J. (2005). The internationalization of higher education: A paradigm for global citizenry. Journal of Studies in International Education, 9(2), 121-136. http://dx.doi.org/10.1177/1028315304263795

Guo, S., \& Chase, M. (2011). Internationalisation of higher education: Integrating international students into Canadian academic environment. Teaching in Higher Education, 16(3), 305-318. http://dx.doi.org/10.1080/13562517.2010.546524

He, N., \& Chen, R. J. C. (2010). College students' perceptions and attitudes toward the selection of study abroad programs. International Journal of Hospitality and Tourism Administration, 11, 347-359. http://dx.doi.org/10.1080/15256480.2010.518525

Horie, M. (2002). The internationalization of higher education in Japan in the 1990s: A reconsideration. Higher Education, 43(1), 65-84. http://dx.doi.org/10.1023/A:1012920215615

Hung, F. (2010). Intention of students in less developed cities in China to opt for undergraduate education abroad: Does this vary as their perceptions of the attractions of overseas study change? International Journal of Educational Development, 30(2), 213-233. http://dx.doi.org/10.1016/j.ijedudev.2009.03.003

Ippolito, K. (2007). Promoting intercultural learning in a multicultural university: Ideals and realities. Teaching in Higher Education, 12(5-6), 749-763. http://dx.doi.org/10.1080/13562510701596356

Knight, J. (2004). Internationalization remodeled: Definition, approaches, and rationales. Journal of Studies in International Education, 8(1), 5-31. http://dx.doi.org/10.1177/1028315303260832

Law, W. (2004). Translating globalization and democratization into local policy: Educational reform in Hong Kong and Taiwan. International Review of Education, 50(5-6), 497-524. http://dx.doi.org/10.1007/s11159-004-4637-4

Lo, W. (2009). Reflections on internationalization of higher education in Taiwan: Perspectives and prospects. Higher Education, 58, 733-745. http://dx.doi.org/10.1007/s10734-009-9209-x

Ma, W. (2002). A study of the rationality of the internationalization and indigenization of education. Chinese Education and Society, 34(6), 78-85. http://dx.doi.org/10.2753/CED1061-1932340678

Marginson, S. (2010). Higher education in the global knowledge economy. Procedia-Social and Behavioral Sciences, 2, 6962-6980. http://dx.doi.org/10.1016/j.sbspro.2010.05.049

Mazzarol, T. W., \& Soutar, G. N. (2008). Australian educational institutions' international markets: A correspondence analysis. International Journal of Educational Management, 22(3), 229-238. http://dx.doi.org/10.1108/09513540810861865 
Mortimer, K. (1997). Recruiting overseas undergraduate students: Are their information requirements being satisfied. Higher Education Quarterly, 51(3), 225-238. http://dx.doi.org/10.1111/1468-2273.00041

Pyvis, D., \& Chapman, A. (2007). Why university students choose an international education: A case study in Malaysia. International Journal of Educational Development, 27(2), 235-246. http://dx.doi.org/10.1016/j.jedudev.2006.07.008

Salisbury, M. H., Umbach, P. D., Paulsen, M. B., \& Pascarella, E. T. (2009). Going global: Understanding the choice process of the intent to study abroad. Research in Higher Education, 50(2), 119-143. http://dx.doi.org/10.1007/s11162-008-9111-x

Sherry, M., Thomas, P., \& Chui, W. H. (2010). International students: A vulnerable student population. Higher Education, 60(1), 33-46. http://dx.doi.org/10.1007/s10734-009-9284-z

Taylor, P., \& Braddock, R. (2007). International university ranking systems and the idea of university excellence. Journal of Higher Education Policy and Management, 29(3), 245-260. http://dx.doi.org/10.1080/13600800701457855

Yang, M., Webster, B., \& Prosser, M. (2011). Travelling a thousand miles: Hong Kong Chinese students' study abroad experience. International Journal of Intercultural Relations, 35(1), 69-78. http://dx.doi.org/10.1016/j.ijintrel.2010.09.010

Yonezawa, A. (2011). The "global 30" and the consequences of selecting "world-class universities" in Japan. In N. C. Liu, Q. Wang, \& Y. Cheng (Eds.), Paths to a world-class university: Lessons from practices and experiences. Rotterdam: Sense Publishers.

\section{Copyrights}

Copyright for this article is retained by the author(s), with first publication rights granted to the journal.

This is an open-access article distributed under the terms and conditions of the Creative Commons Attribution license (http://creativecommons.org/licenses/by/3.0/). 